\title{
First report of tomato bacterial canker Clavibacter michiganensis subsp. michiganensis on tomato crops in Arica
}

\author{
Primer reporte de cancro bacteriano Clavibacter michiganensis \\ subsp. michiganensis en plantas de tomate en Arica \\ Germán F. Sepúlveda Chavera ${ }^{1 *}$, Ricardo Salvatierra Martínez ${ }^{1}$, Claudio Sandoval Briones ${ }^{2}$, \\ Robinson González Vásquez ${ }^{1}$
}

\begin{abstract}
We report the isolation and determination of Clavibacter michiganensis subsp. michiganensis $(\mathrm{Cmm})$ in tomato plants grown in greenhouses in the Azapa Valley with symptoms consistent in bacterial canker. Determination was based on growth on selective media and serological tests. This is the first record of $\mathrm{Cmm}$ in the Azapa valley.
\end{abstract}

Key words: bacterial spot disease, grafted tomato, horticultural crops.

\section{RESUMEN}

Se informa el aislamiento y determinación de Clavibacter michiganensis subsp. michiganensis $(\mathrm{Cmm})$ en plantas de tomate bajo malla en el valle de Azapa, y sintomatología consistente con cancro bacteriano. La determinación se realizó a partir de crecimiento en medios selectivos y pruebas serológicas. Este es el primer registro de $\mathrm{Cmm}$ en el valle de Azapa.

Palabras clave: mancha bacterial, tomate injertado, cultivos hortícolas.

\section{Introduction}

In the region of Arica and Parinacota, Chile, the tomato (Solanum lycopersicum L.) is the most cultivated vegetable, mainly in the Azapa Valley, where it is grown intensively and the highest yields of the country are obtained (ODEPA, 2010). Arica sustains tomato consumption in Chile in winter (June to October); around 700 ha are cultivated annually, $13 \%$ of the area planted in tomatoes for fresh consumption in the country (ODEPA, 2012).

One of the most important phytopathological problems in the tomato producing areas in Chile is bacterial canker disease, known until 1983 as Corynebacterium michiganensis but currently classified as Clavibacter michiganensis subsp. michiganensis (Cmm) (Gleason et al., 1993) The plant pathogen was first identified and studied in Chile by Nome and Docampo, (1969) and Latorre and Nome, (1970); in the tomato production in Quillota it is one of diseases to which most attention has been given
(Besoain y Chaguan, 2007; Besoain et al., 2000; Vega et al., 2000; Alvarez et al., 1995; Riquelme et al., 1994), since this disease is characterized by severe attacks both outdoors and in greenhouses (Chang et al., 1991). The first symptom of the disease is marginal wilting of leaflets; necrotic streaks subsequently appear, extending from the bottom of the stem to the point where it joins the stem stalk. Under certain conditions the necrotic spots may open and cankers occur as a secondary source of infection (Borboa et al., 2009); infected plants can survive until harvest and sporadically small necrotic spots surrounded by a clear halo appear in the fruit, which are known as "bird's eyes" (Blancard, 1996). In the Azapa Valley there were no records of symptoms of bacterial canker attacks before the 2012 season.

The aim of this note is to record the presence and identification of Clavibacter michiganensis subsp. michiganensis (Smith), tomato bacterial canker in greenhouses in the Azapa Valley region of Arica and Parinacota, Chile.

\footnotetext{
Facultad de Cs. Agronómicas, U. Tarapacá. Avda. General Velásquez 1775, Arica.

2 Facultad de Agronomía, U. de Talca. 2 Norte 685, Talca-Chile.

* Autor por correspondencia: gsepulve@uta.cl
} 


\section{Materials and Methods}

\section{Bacterial isolation and identification}

In December, 2012 tomato plants of the commercial cultivar Luciana ${ }^{\circledR}$ (=Airton) grafted on commercial rootstocks Amstrong ${ }^{\circledR}$ (Syngenta, Switzerland) with symptoms of bacterial canker
(Figure 1) were collected in two greenhouses in the Azapa valley. The bacteria were isolated from the plant samples in nutritive media (King B) (Merck, Chile). Isolates were initially identified on the basis of colony characteristics and cell morphology (color, shape, motility and size), and Gram's reaction with 3\% KOH (Gregersen, 1978). The species was subsequently identified from growth

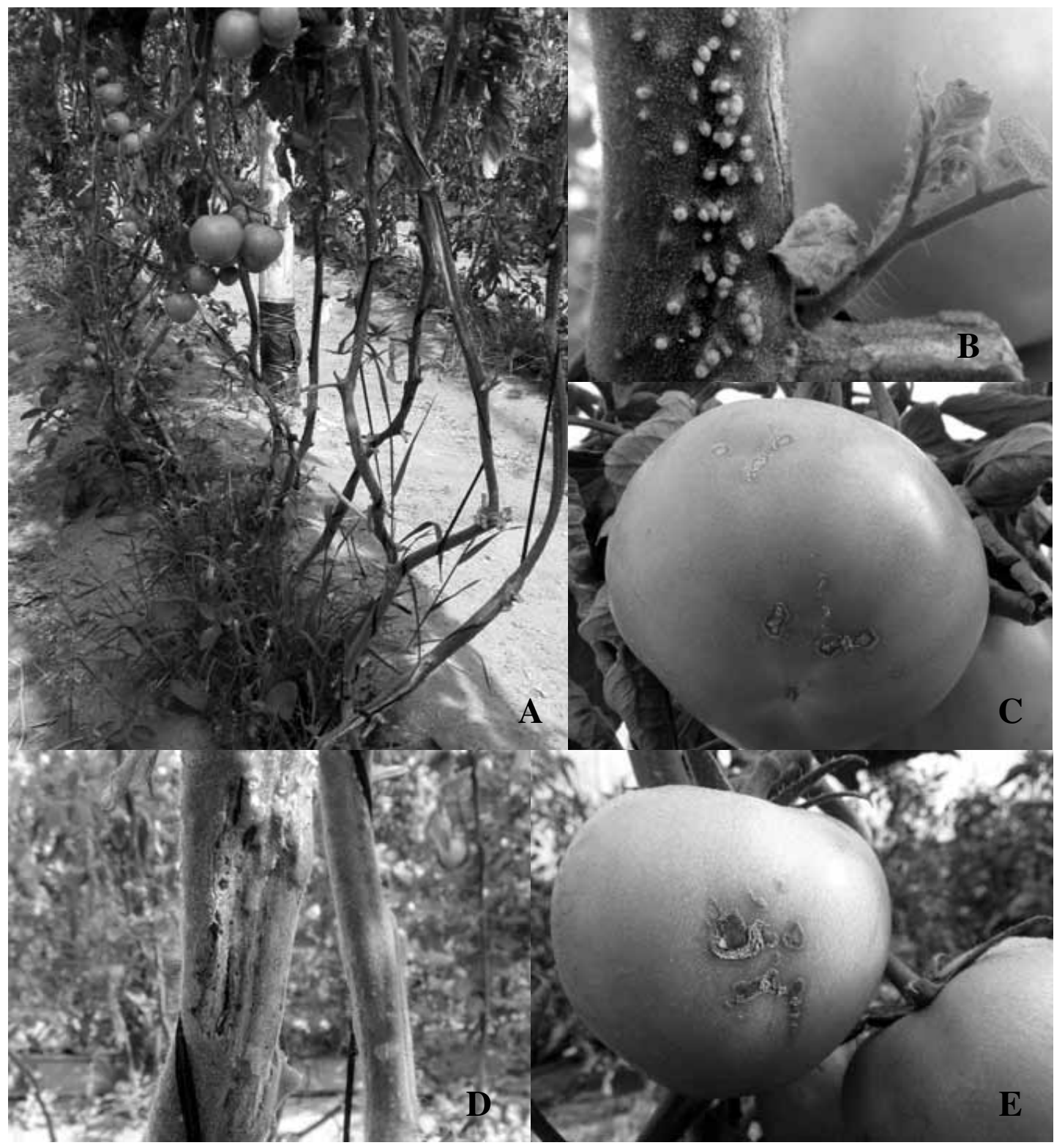

Figure 1. Symptoms of Cmm in Tomato plants and fruit. A: Field symptoms of Tomato Bacterial Canker on commercial cultivar Luciana ${ }^{\circledR}$ grafted on commercial rootstocks Amstrong ${ }^{\circledR}$ (Syngenta, Switzerland). B: Adventicious root in stem of tomato plants. $\mathrm{C}$ and E: Bird's eye lesion on tomato fruit. D: Stem canker on tomato plant. 
and comparison of three semi-selective media sCNS (Shepherd, 1999), mSCM (Bolkan et al., 1996) and $\mathrm{D}_{2} \mathrm{ANX}$ (Chun, 1982) and the result of $\mathrm{Cmm}$ specific serological tests (Inmuno-strip ${ }^{\circledR}$, AGDIA incorporated, USA) that was performed on the colonies and plant samples.

\section{Results}

All colonies isolated listed were Gram + and subsequently identified as $\mathrm{Cmm}$ according to their morphology on selective media and the positive result in the serological test. In Azapa Valley there were no records of attack symptoms of bacterial canker until the 2012 season; its presence may be associated with the use of seedlings of tomatoes of other regions where the disease is present. In the future we will use PCR identification and pathogenicity tests to provide more conclusive results.

\section{Acknowledgements}

Thanks to Project Cod. 9742-2012 and FIA PYT 2012-0024 for financial support.

\section{Bibliographic References}

Alvarez, C.; Besoaín, X.A. y Salgado, E.

2000. Evaluación del bactericida Agrygent 5000 plus en el control del cancro bacteriano (Clavibacter michiganensis subsp. michiganensis) en tomate. X Congreso chileno de Fitopatología. Valdivia - Chile.

Besoain, X. y Chahuán, J.

2007. Sensibilidad de diez cepas de Clavibacter michiganensis Subs. michiganensis a Kasugamicin. XVII Congreso chileno de Fitopatología Concepción - Chile.

Besoain, X.; Corvalán, C.; Peñaloza, P. y Briceño, E. 2000. Evaluación de bromuro de metilo y corteza de pino y su efecto sobre inoculo de cancro bacteriano del tomate. X Congreso chileno de Fitopatología. Valdivia - Chile.

Blancard, D. 1996. Enfermedades del tomate. INRA Estación de Patología. Ed. Mundi-Prensa. España. 109 pp.

Bolkan, H.A.; Waters, C.M. and Fatmi, M.

1996. ISTA Handbook On Seed Health Testing, Working Sheet $\mathrm{N}^{\circ} 67$. Zurich, Switzerland.

Borboa, J.; Rueda, E.; Acedo, E.; Ponce, F.; Cruz, M.; Grimaldo,

O. y García, A.

2009. Detección de Clavibacter michiganensis subsp. michiganensis en el tomate del estado de Sonora, México. Rev. Fitotc. Méx. 32: 319-326.

Chang, R.J.; Ries, S.M. and Pataky, J.K.

1992. Local sources of Clavibacter michiganensis subsp. michiganensis in the development of bacterial canker on tomatoes. Phytopathology 82: 553-560.

Gleason, M.; Braun, E.J. and Peterson, R.H.

1993. Survival and dissemination of Clavibacter michiganensis sups. michiganensis in tomatoes. Phytopathology 81: 1519-1523.

Chun, W.C.C.

1982. Identification and detection of Corynebacterium michiganense in tomato seed using the indirect enzime-linked immunosorbent assay. MSc Thesis, University of Hawaii, Honolulu, HI, USA.

Latorre, B.A. y Nome, H.F.

1970 Survival of the causal organism of tomato bacterial canker (Corynebacterium michiganense) in the soil. Agricultura Técnica 30 (4): 192-195.

Nome, H.F. y Docampo, Q.D.

1969. Cancro bacteriano del tomate (Corynebacterium michiganense) (E.f. Smith) Jensen Chile. Estac. Exp. Agron. Bol. Tec. 29: 23-26.

ODEPA.

2010. Información hortícola (publicación especial) 20082009. Publicación de la Oficina de Estudios y Políticas Agrarias - ODEPA, Ministerio de Agricultura. Gobierno de Chile, Santiago, Chile, pp. 128.

ODEPA.

2012. Situación del tomate para consumo fresco. Publicación de la Oficina de Estudios y Políticas Agrarias - ODEPA, Ministerio de Agricultura. Gobierno de Chile, Santiago, Chile, pp. 6.

Riquelme, M.; Besoain, X.; Arellano, C.; Arellano, M.; Cifuentes,

J.; Guerrero I.; Duimovic; A. y Arancibia, R.

1994. Incidencia de Cancro bacteriano en tomates cultivados en invernaderos fríos en la provincia de Quillota, Chile. IV Congreso chileno de Fitopatología. Santiago, enero.

Shepherd, L.M.

1999. Detection and transmission of Clavibacter michiganensis subsp. nebraskensis of corn. Ms Thesis, Iowa State University, Ames, IA. USA. 158 pp.

Vega, E.; Ureta, T. y Campos, G.

2000. Aumento de la incidencia de Clavibacter michiganensis subsp. michiganensis, agente causal de la enfermedad cancro bacteriano del tomate, en el cultivo del tomate de la última temporada. X Congreso chileno de Fitopatología. Valdivia - Chile. 
